\title{
Effect of the Flipped Classroom Model on Chinese Non-English-Majored College Students' Translation Skills
}

\author{
Yougen Lou' ${ }^{1}$, Yueqing Du${ }^{1}$, Zejuan Li ${ }^{1}$, Pin Gong1, Yangmei Li ${ }^{2}$ \\ ${ }^{1}$ School of Foreign Studies, Yangtze University, Jingzhou City, China \\ ${ }^{2}$ Gong'an County No. 1 Middle School, Gong'an, China \\ Email: louyougen@163.com
}

How to cite this paper: Lou, Y.G., Du, Y.Q., Li, Z.J., Gong, P. and Li, Y.M. (2017) Effect of the Flipped Classroom Model on Chinese Non-English-Majored College Students' Translation Skills. Open Journal of Social Sciences, 5, 270-281.

https://doi.org/10.4236/jss.2017.54024

Received: March 12, 2017

Accepted: April 27, 2017

Published: April 30, 2017

Copyright $\odot 2017$ by authors and Scientific Research Publishing Inc. This work is licensed under the Creative Commons Attribution International License (CC BY 4.0). http://creativecommons.org/licenses/by/4.0/

\section{Open Access}

\begin{abstract}
This paper reviewed a one-term experiment on the flipped classroom model in teaching translation skills to 124 first-year non-English-majored undergraduate students from Yangtze University as participants. Participants in this study consisted of 62 non-English-majored undergraduate students in the control group (CG) and 62 non-English-majored undergraduate students in the treatment group (TG). The process of the flipped classroom model in translation teaching and learning was divided into the three parts: outside of the flipped classroom, inside of the flipped classroom and outside of the flipped classroom. The results showed that: 1) compared with a teacher-dominated approach for CG, the flipped classroom translation model instruction for TG did a better job in enhancing students' translation skills; 2) there were significant differences between males in CG and TG, and females in CG and EG; 3) students in TG held the positive response for the flipped classroom model in translation teaching and learning.
\end{abstract}

\section{Keywords}

The Flipped Classroom, Translation Class, Performances

\section{Introduction}

Technology influences not only our daily life but also our teaching and learning method! Especially, the new technology (such as big data, computer aided design, computer aided translation) and new methods (such as massive open online course, the flipped classroom) applied into education affect our teaching and learning deeply when we come into the new era, 21st century. The flipped classroom approach was started in 2006 in Colorado, and the model basically 
refers to the idea that the lectures and explanations would no longer be done in class but at home, leaving what was previously treated as homework to be done in the class time [1]. The flipped classroom approach is student-centered teaching and learning method. The flipped classroom agrees with the theory of Constructivism. According to the theory of Constructivism, knowledge is not taught but is learned by the learner himself through constructing the new knowledge on the basis of old knowledge, under certain settings, with the help of others, such as the teachers or learning partners, utilizing certain study resources. So the student is the center of teaching and student-centered methodology should be used. That is to say, the student is the center of teaching and the teacher works as the organizer, facilitator and motivator, utilizing setting, cooperation and dialogue to motivate students' interests, activities and creativeness. Before the flipped classroom, students can know the learning tasks and they can learn to complete the learning tasks by watching the videos made by the instructors to construct the new knowledge. And in class, the instructors organize and guide the students to cooperate with each other to discuss the questions in their learning and what they have learned, so students can gain help of the teachers or learning partners.

\section{Literature Review}

According to Bergmann \& Sams [1], a flipped classroom can be described as a setting where that "which is traditionally done in class is now done at home, and that which is traditionally done as homework is now completed in class" (p. 13). The flipped classroom model changes the view of the classroom from being a knowledge station to being a place for student engagement and formative assessment of students' progress [2].

There are benefits and challenges to adopt the flipped classroom model in education. Benefits to implementing the flipped classroom model include students learning at their own pace, reinforcing the teacher-student relationship [1] Studies by Aljumah [3] and Al-Kathiri [4] showed students benefitted from the use of technology in learning English. On the other hand, there are some challenges with accompanying the implementation of the flipped classroom model such as students having difficulty adjusting to being active learners or neglecting to do the out-of-class work [5] [6]. Another challenge is that teachers are not willing or capable of changing and adopting the use of technology [7].

The flipped classroom approach is spread all over the world. Allison J. James et al. [8] studied application of the flipped classroom in maritime education. Eunicia TAN et al. [9] evaluated the relative acceptability of the flipped classroom approach compared with traditional didactics for in-house teaching in emergency medicine and found that ninety-eight per cent (48/49) of respondents preferred the flipped classroom over the traditional approach. Tracey Muir \& Vince Geiger [10] (2016) reported that they made a case study of a grade $10 \mathrm{ma}-$ thematics class by using a flipped classroom approach and found that the teacher and students were positive about their experiences with a flipped classroom approach and that students were motivated to engage with the teacher-created on- 
line mathematics resources. David Gonza'lez-Go'mez et al. [11] (2016) evaluated the effectiveness of a new teaching methodology in a general science classroom in the Flipped Learning Model, and they found that a statistically significant difference was found on all assessments with the flipped class students performing higher on average; most students had a favorable perception about the flipped classroom noting the ability to pause, rewind and review lectures, as well as increased individualized learning and increased teacher availability. The above foreign researchers studied application of the flipped classroom in the fields of natural science. Vasiliki Aidinopoulou and Demetrios G. Sampson [12] focused on the implementation of the flipped classroom model in social studies (history teaching and learning) in primary school.

In China, there were studies on the flipped classroom model. Pan Bingchao [13] studied effects of the flipped classroom on 127 undergraduate students in learning the course: Design and production of multimedia courseware and he found the flipped classroom model could stimulate and maintain college students' learning motivation, cultivate college students' autonomous learning and cooperative learning ability. Kaushal Kumar Bhagat et al. [14] investigated the effects of flipped classrooms on learners with different achievement levels in learning mathematics concepts. And they found a significant difference in the learning achievement and motivation between the experimental and control groups with students using the flipped classroom performing better and a significant difference in the performance of low achievers in the two groups. Feng-Kuang Chiang \& Chen Chen [15] examined the three-year application of the modified flipped classroom model in a postgraduate course on learning sciences and they found that the modified flipped classroom can effectively bring out students' initiative and improve both their learning satisfaction and empirical research abilities.

From the above information, we may find that there are more studies the flipped classroom model applied in the field of natural science (such as maritime education, emergency medicine), only a few studies [12] [13] of the flipped classroom model applied in the field of social science, but few studies of the flipped classroom model on the translation teaching and learning. This paper will investigate the effects of the flipped classroom model on non-English-majored undergraduate students' translation teaching and learning.

\section{Methodology and Data Collection}

\subsection{Research Design}

This study included two quantitative components(two tests related to translation skills)to provide the information on non-English-majored undergraduate students' translation skills before and after trained by the flipped classroom model, and a qualitative component (open-ended interview) to provide the perceptions of non-English-majored undergraduate student towards the use of flipped classroom model. The following research questions were answered in this study:

1) As a result of implementing the flipped classroom model, were there any 
significant differences between CG's and TG's improvement in relation to translation skills?

2) Was there any significant difference between male non-English-majored undergraduate students and female non-English-majored undergraduate students in CG and TG.

3) What were non-English-majored undergraduate students' perceptions towards implementing the flipped classroom in translation learning? What are the benefits of using video lecture in the flipped classroom?

\subsection{Participants}

In September 2016, 124 first-year non-English-majored Chinese undergraduates majored agriculture, plant protection, chemistry from Yangtze University were volunteers in this study. 124 freshmen, taught by the same male instructor during the whole academic term (September, 2016 to January, 2017), were 71 females and 53 males, their average age 18, Chinese as their first or mother language. All 124 participants were divided randomly into two groups: 62 participants as the Control Group (CG) with the traditional undergraduate translation method and 62 participants as the Treatment Group (TG) with the flipped classroom model. Both CG and TG had the similar level of education background, family background, personality and life experiences, which was to say, their overall learning and cognitive abilities were almost equal.

\subsection{Instruments}

The instruments used in this study were tests on translation applied ability and an interview with undergraduate students from TG on flipped classroom model.

Translation applied ability pre-test: All the 124 non-English-majored undergraduates were attended the translation applied tests (translation from English to Chinese (10) and translation from Chinese to English (10), total 20) at 14:30-15:30 on September 19, 2016 in one classroom to gain students' translation applied ability in CG and TG before the experiment. All the 124 non-Englishmajored under graduates were required to complete the tests in one hour. The translation applied ability tests materials (translation from English to Chinese) were taken from translation part of June, 2015 National College English Test 4 (CET 4) and the translation applied ability tests materials (translation from Chinese to English) were taken from translation part of June, 2014 National College English Test 4 (CET 4).

Translation applied ability post-test: All the 124 non-English-majored undergraduates were attended the translation applied tests (translation from English to Chinese (10) and translation from Chinese to English (10), total 20) at 14:30-15:30 on January 8, 2017 in one classroom to gain students' changes in translation skills, ability between CG and TG after the experiment. All the 124 non-English-majored undergraduates were required to complete the tests in one hour. The translation applied ability tests materials (translation from English to Chinese) were taken from translation part of December, 2015 National College 
English Test 4 (CET 4) and the translation applied ability tests materials (translation from Chinese to English) were taken from translation part of December, 2014 National College English Test 4 (CET 4).

Interview: After the experiment, all 62 participants in TG in this experiment were interviewed via QQ (a kind of on-line instant message service tool in China) lasted two weeks and were required to fill out the interview questions: 1) Do you think the flipped classroom model has improved your translation skills or ability? 2) What are difficulties when you participate in the flipped classroom in translation learning? 3) Do you think the flipped classroom model in the translation teaching is beneficial to all 62 graduate students in TG?

\subsection{Data Collection and Analysis}

Two tests on translation skills or ability (translation from English to Chinese and translation from Chinese to English) before the research experiment (September 19, 2016) and two tests on translation ability (translation from English to Chinese and translation from Chinese to English) after the experiment (January 8, 2017) were conducted to compare the changes between the two groups(CG and TG) of non-English-majored undergraduate students in the ability of translation from English to Chinese. Comparison of Means was adopted to compare two groups of non-English-majored undergraduate students' average scores of their pre-test and post-test on the basis of samples. And the independent sample T-test was adopted to examine if there were significant differences between CG and TG before the experiment and after the experiment. Also the independent sample T-test was adopted to examine if there were significant differences between male and female graduate students in CG and TG.

\section{Process of the Flipped Classroom Model in Translation Teaching and Learning}

Approach to Translation between English and Chinese published by Foreign Language Teaching and Research Press as the textbook was used in teaching translation for non-English-majored undergraduates in CG and TG. In the experiment, participants in the control group were instructed by the traditional translation model (teachers explaining translation skills and students listening to teachers' translation instruction). However, participants in the treatment group were instructed by the flipped classroom model. The flipped classroom model in translation learning in this study was divided into three parts. The first part was outside of the flipped classroom in translation; the second part was inside of the flipped classroom in translation; and the third part was outside of the flipped classroom in translation.

The instructor's activities and students' activities were included in the three parts of the flipped classroom model in translation teaching and learning. The first part, outside of the flipped classroom in translation, the translation instructor needs analysis and design in translation teaching, the content selection and video production in translation teaching, creation of autonomous learning situa- 
tion and design of strategies in autonomous learning, preparation of translation teaching in class. During the first part, the translation instructor needs select the translation teaching content and produce a short translation teaching content video such as 10 - 15 minutes' direct translation theory video according to the translation teaching The first part, outside of the flipped classroom in translation, the students' activities include understanding translation learning tasks, watching translation teaching videos (such as 10 - 15 minutes' direct translation theory video) made by the translation instructor to complete translation learning tasks, self-test the translation knowledge (such as subtitle translation) before class and summary of translation learning through watching translation teaching videos before class. The students can communicate with the translation instructor about translation learning via the communication platform if students want to ask the instructor questions related to translation. The second part, inside of the flipped classroom in translation, the translation instructor create the translation teaching and learning environment, then organize and guide students learning translation through independent study, collaborative learning, achievement exchange and reports. The translation instructor can organize 3 - 4 students per group according to their wills and guide every group cooperative learning such as solving their translation learning problems by discussion. Then the representative of every group reports his or her group's translation learning achievement. Inside of the flipped classroom in translation, the translation instructor not only organizes and guides the students' translation learning activities but also joins in their discussion to scaffold students' translation learning. The third part, outside of the flipped classroom in translation, the students need write their lesson summary and evaluation about translation learning in class, and give their lesson summary and evaluation to their translation instructor; then the instructor gives students the comprehensive evaluation and feedback of their translation learning.

\section{Results}

The results in this study included three parts. The first part was translation test results of pre-test and post-test between the control group (CG) and the treatment group (TG). The second part was whether there were significant differences between males and females, as CG with a traditional translation teaching model compared to TG with the flipped classroom translation model. The last part was that responses to the interview on the flipped classroom in translation teaching and learning from non-English-majored undergraduates in TG.

\subsection{Effects of the Flipped Classroom Model of Translation Instruction and Traditional Translation Method on Non-English-Majored Undergraduates' Translation Performance}

From Table 1, we could see non-English-majored undergraduate students' translation performance from CG and TG before and after the experiment. The re- 
sults from Table 1 showed translation tests' (translation from English to Chinese (10) and translation from Chinese to English (10), total 20) scores between CG and TG taught by different translation methods in the pre-tests' scores between CG and TG and their post-tests' scores between CG and TG. In the pre-tests of translation skill between the two groups (CG, TG), there was no significant difference $(\mathrm{t}=0.771, \mathrm{P}=0.444)$ between $\mathrm{CG}(\mathrm{M}=9.887, \mathrm{~S} 2.523)$ and $\mathrm{TG}(\mathrm{M}=$ $9.548, S=2.487)$. However, in the post-tests, a significant difference was found between $C G(M=9.936, S=1.668)$ and $(M=10.468, S=1.657)$ in the translation tests, $(\mathrm{t}=-2.262, \mathrm{P}=0.027)$. After the instruction of the flipped classroom model in translation skills, the participates' translation mean scores of TG (M = 10.468) were higher than that of the participants' translation mean scores of CG $(\mathrm{M}=9.936)$.

\subsection{Results of the T-Test about Males and Females in CG and TG Taught by Different Translation Approach}

From Table 2, there were significant differences between males and females in the two groups: $\mathrm{CG}$ and TG. Males $(\mathrm{P}=0.02)$ suggested that there was the significant difference between CG and TG in their translation ability after the KWL plus model of meta-cognitive translation strategy instruction with support of IBLL and females $(P=0.01)$ suggested that there was a significant difference between CG and TG in their translation ability after the KWL plus model of meta-cognitive translation strategy instruction with support of IBLL.

\subsection{Results of Responses of the interview from Non-English-Major Undergraduates in TG on Instructing Translation through the Flipped Classroom Model}

Before the experiment of the flipped classroom on non-English-majored undergraduate students' translation skills was ended, an interview was held at 14:30-

Table 1. Results of non-English-major undergraduates' translation scores of pre-test and post-test.

\begin{tabular}{cccccccc}
\hline \multirow{2}{*}{ Tests } & \multicolumn{2}{c}{ CG $(\mathrm{N}=62)$} & \multicolumn{2}{c}{ TG $(\mathrm{N}=62)$} & \multirow{2}{*}{$\mathrm{t}$} & $\mathrm{P}$ \\
\cline { 2 - 5 } Groups & $\mathrm{M}$ & $\mathrm{S}$ & $\mathrm{M}$ & $\mathrm{S}$ & & \\
\hline Pre-test & 9.887 & 2.523 & 9.548 & 2.487 & 0.771 & 0.444 \\
Post-test & 9.936 & 1.668 & 10.468 & 1.657 & -2.262 & 0.027 \\
\hline
\end{tabular}

$\mathrm{M}$ stands for Mean; $\mathrm{S}$ stands for standard deviation; ${ }^{*} \mathrm{P}<0.05 ;{ }^{*} \mathrm{P}<0.01$.

Table 2. Results of the T-Test about Males and Females in CG and TG taught by different translation approach.

\begin{tabular}{cccc}
\hline T(two-tailed) & Gender & Males & Females \\
\hline Probability & $0.02^{\star}$ & $0.01^{\star}$
\end{tabular}

${ }^{\star} \mathrm{P}<0.05 ;{ }^{*} \mathrm{P}<0.01$ 
16:30 on January 3, 2017 in a classroom to gain the responses from non-English-majored undergraduate students in TG on the new translation teaching and learning method of the flipped classroom. All the 62participants in TG as volunteers attended the interview to provide their answers to the following three written questions: 1) Do you think the flipped classroom model in translation teaching and learning has improved your translation skills and translation ability? 2) Was it difficult for you to apply the flipped classroom model in your translation learning and translation practice? If, yes. What were your difficulties? 3) Do you think the flipped classroom model was beneficial to all of you in TG in the translation learning?

Among 62participants in TG, 51 participants said that although they had to spend the more time in the translation learning due to watching the translation teaching videos and completing the translation learning tasks before the translation class, the flipped classroom model had improved their translation skills and translation ability because they could watch the translation teaching videos made by their translation instructor and they could discuss the translation problems (such as direct translation, subtitles in screen translation, translation of terminology in different fields) they met with their classmate or the translation instructor in class if they had the translation questions, and they could gain their comprehensive translation evaluation from their translation instructor; 8 participants told that it was difficult for them to complete their translation learning tasks through watching the translation teaching videos made by the translation instructor, and they also thought whatever translation from English to Chinese or translation from Chinese to English was difficult to them because they could not spend the more time in translation learning by themselves out of the flipped classroom and did not know how to discuss their translation questions with their group members in class; 3 participants said that they did not have ideas on the flipped classroom model in their translation skills and translation ability. 54 participants thought the flipped classroom model in translation teaching and learning was beneficial to their translation performance and improvement of their translation skills, translation ability; but 8participants thought the flipped classroom model in translation teaching and learning was not beneficial to them, because their Chinese and English level were not good.

\section{Discussion}

The authors in this study want to investigate the answers to the three questions. One of the purposes in this study is to investigate if the translation instruction through the flipped classroom model can improve non-English-majored undergraduates' translation skills and translation ability. Improvement of participants' translation skills and translation ability in TG shows the important role of the flipped classroom model played for non-English-majored undergraduates' translation learning.

Through results in Table 1, we could know that after the different translation instruction methods: the traditional method for CG and the flipped classroom 
model for TG, both participants' translation scores in CG and participants' translation scores in TG were improved. However, the TG's translation scores were higher than that of the CG's, which means that the flipped classroom model can improve non-English-majored undergraduates' translation skills and translation ability in TG trained by the new translation method. The flipped classroom model encourages students to watch the translation teaching videos made by the translation instructor to complete their translation tasks before class to learn the translation knowledge such as translation theories, screen translation, machine translation by themselves, and they are organized or guided by their translation instructor to share what they have learned about translation or to discuss their translation questions with their classmates in groups in class to get help from the classmates or instructor, after class they can get their comprehensive translation evaluation from their translation instructor, then their translation skills and translation ability can be improved by the training of the flipped classroom model. We may find that the flipped classroom model agrees with the theory of Constructivism to encourage students learn knowledge by themselves (according to he theory of Constructivism, knowledge is not taught but is learned by the learner himself through constructing the new knowledge on the basis of old knowledge, under certain settings) and the flipped classroom model, provides students help from their classmates or their instructor, agrees with he theory of Constructivism (with the help of others, such as the teachers or learning partners), and utilizes certain study resources (such as teaching videos , online resource and smart phones).

After trained by the flipped classroom approach, most of male and female non-English-major undergraduate students in TG successfully learn to know how to improve their translation skills, ability by completing their translation tasks and learn translation knowledge such as translation theories, screen translation, machine translation and they discuss their translation questions with their groups or their translation instructor to get help from them, so they show better in translation skills and translation ability, compared with male and female non-English-major undergraduates in CG. And there are significant differences between males and females in CG and TG. Male and female non-English-major undergraduate students in TG could have the opportunity to discuss the problems or difficulties with their group members or their translation instructor, so they could find their group members or their translation instructor to help them solve the problems or difficulties they had during their discussion or translation process, which would provide chances for non-English-major undergraduate students in TG to improve their translation skills and translation ability by solving their translation problems or difficulties.

Non-English-major undergraduates in TG generally holding positive responses for the flipped classroom model suggests that the flipped classroom model applied into regular non-English-majored undergraduate students translation curriculum is a worthy try. Translation will be as a tool for non-English-majored undergraduates to recommend the Chinese culture and advanced technology to 
the people all over the world. At the same time, non-English-majored undergraduates could recommend advanced science and technology in western countries to China and Chinese readers by the useful tool, translation. Non-Englishmajored undergraduate students need practice translating and revising more academic-style materials related to their majors, the method of the flipped classroom is tentative method for non-English-majored undergraduates to learn how to translate and monitor how to relate their prior translation knowledge Although 51participants in TG think the flipped classroom model has improved their translation skills and translation ability, but the flipped classroom translation teaching and learning model is not beneficial to all 62 participants in TG, so the instructor needs help solve learners' learning difficulties such as how to improve their Chinese and English level.

\section{Limitations and Suggestions for Further Research}

Though the present study has investigated a survey of the flipped classroom model among the 62 non-English-majored undergraduate students in translation teaching and learning, there are still some limitations in the study. There are limitations in this article.

Firstly, time limitation (only 4 months) and other practical restrictions such as the subjects in the study consisted of only 124 non-English-majored undergraduate students in one university are needed to be broadened in further research.

Secondly, the instruments used in this study to investigate the non-Englishmajored undergraduate students' translation skills instruction involve two tests to measure non-English-majored undergraduate students' translation skills. The study would be much better, if it were combined with other instruments such as verbal report. More instruments should be used in investigating in the further research.

Finally, participates in this study were the non-English-majored undergraduate students in only one university. The study will be better if more participates from other universities can be participated in the experiment. Results of other subjects' translation skills such as high school students, English-majored undergraduates and non-English-majored graduates, we need further research.

Despite of the restraints of the study, we hope that it can offer some guidelines for further research of the flipped classroom model on non-English-majored graduate students' translation skills.

\section{Conclusion}

This paper investigated an experiment (September 19, 2016 to January 8, 2017) on effects of the flipped classroom model in teaching and learning translation skills and translation ability on 124 first-year non-English-majored undergraduate students from Yangtze University as participants. Participants in this study consisted of 62 non-English-majored undergraduates in the control group (CG) and 62 non-English-majored undergraduates in the treatment group (TG). The results showed that 1) compared with a teacher-dominated translation tea- 
ching and learning approach for CG, the flipped classroom model for TG did a better job in enhancing students' translation skills and translation ability; 2) there were significant differences between males in CG and TG, and females in CG and TG; 3) students in TG held the positive response for the new translation teaching and learning method (the flipped classroom model), but the flipped classroom model is not beneficial to the students whose Chinese and English level are not good and students have to spend more time to learn translation knowledge by themselves through watching translation teaching videos online. This study is a worthy try on the flipped classroom model in translation teaching and learning. We hope this paper could provide the information for the future research on translation teaching and learning.

\section{References}

[1] Bergmann, J. and Sams, A. (2012) Flip Your Classroom: Reach Every Student in Every Class Every Day. Teaching Theology \& Religion, 17, 82-83.

[2] Kang, N. (2015) The Comparison between Regular and Flipped Classrooms for EFL Korean Adult Learners. Multimedia-Assisted Language Learning, 18, 41-72.

[3] Aljumah, F.H. (2012) Saudi Learner Perceptions and Attitudes towards the Use of Blogs in Teaching English Writing Course for EFL Majors at Qassim University. English Language Teaching, 5, 100.

[4] Al-Kathiri, F. (2015) Beyond the Classroom Walls: Edmodo in Saudi Secondary School EFL Instruction, Attitudes and Challenges. English Language Teaching, 8, 189-204.

[5] DewiSuryani, A. (2014) The Use of "Flipping Classroom" for Teaching Story-Telling to the Tenth Graders. E-Journal of Universitas Negeri Surabaya.

[6] Huelskamp, D. (2015) Flipping the Collegiate Science Classroom: A Review of the Research. Global Education Journal, 2015, 61-72.

[7] Educause Learning Initiative (2012) 7 Things You Should Know about Flipped Classrooms. http://net.educause.edu/ir/library/pdf/ELI7081.pdf

[8] James, A.J., Chin, C.K.H. and Williams, B.R. (2014) Using the Flipped Classroom to Improve Student Engagement and to Prepare Graduates to Meet Maritime Industry Requirements: A Focus on Maritime Education. WMU Journal of Maritime Affairs, 13, 331-343. https://doi.org/10.1007/s13437-014-0070-0

[9] Tan, E., Brainard, A. and Larkin, G.L. (2015) Acceptability of the Flipped Classroom Approach for In-House Teaching in Emergency Medicine. Emergency Medicine Australasia, 27, 453-459. https://doi.org/10.1111/1742-6723.12454

[10] Muir, T. and Geiger, V. (2016) The Affordances of Using a Flipped Classroom Approach in the Teaching of Mathematics: A Case Study of a Grade 10 Mathematics Class. Mathematics Education Research Journal, 28, 149-171. https://doi.org/10.1007/s13394-015-0165-8

[11] González-Gómez, D., Jeong, J.S., Airado Rodríguez, D. and Airado Rodríguez, F. (2016) Performance and Perception in the Flipped Learning Model: An Initial Approach to Evaluate the Effectiveness of a New Teaching Methodology in a General Science Classroom. Journal of Science Education and Technology, 25, 450-459. https://doi.org/10.1007/s10956-016-9605-9

[12] Aidinopoulou, V. and Sampson, D.G. (2017) An Action Research Study from Implementing the Flipped Classroom Model in Primary School History Teaching and Learning. Educational Technology \& Society, 20, 237-247. 
[13] Pan, B. (2015) Experimental Study on Application of Flipped Classroom Model in College Teaching. Curriculum and Instruction, 3, 83-88.

[14] Bhagat, K.K., Chang, C.-N. and Chang, C.-Y. (2016) The Impact of the Flipped Classroom on Mathematics Concept Learning in High School. Educational Technology \& Society, 19, 134-142.

[15] Chiang, F.-K. and Chen, C. (2017) Modified Flipped Classroom Instructional Model in "Learning Sciences" Course for Graduate Students. The Asia-Pacific Education Researcher, 26, 1-10. https://doi.org/10.1007/s40299-016-0321-2

Submit or recommend next manuscript to SCIRP and we will provide best service for you:

Accepting pre-submission inquiries through Email, Facebook, LinkedIn, Twitter, etc. A wide selection of journals (inclusive of 9 subjects, more than 200 journals)

Providing 24-hour high-quality service

User-friendly online submission system

Fair and swift peer-review system

Efficient typesetting and proofreading procedure

Display of the result of downloads and visits, as well as the number of cited articles Maximum dissemination of your research work

Submit your manuscript at: http://papersubmission.scirp.org/

Or contact jss@scirp.org 